\title{
Peran Strategi Mengajar Guru Terhadap Prestasi Belajar Siswa Kelas V Di SD Kristen Kalam Kudus Makassar
}

\author{
Novita Pe'pan, Sarce Rien Hana
}

\begin{abstract}
Abstrak
Metode penelitian yang digunakan dalam penelitian ini adalah kuantitatif. Hasil penelitian menunjukkan sebagai berikut. (1) Dari ketiga guru yaitu guru Bahasa Indonesia, Matematika dan IPA semuanya sudah sangat berperan aktif dalam proses belajar mengajar. (2) Dari ketiga guru tersebut semuanya sudah menggunakan strategi mengajar dalam meningkatkan prestasi belajar siswa. Strategi yang digunakan guru Bahasa Indonesia yaitu diskusi dan tanya jawab, guru Matematika menggunakan strategi ekspositori dan deduktif dan guru IPA menggunakan strategi ceramah dan praktik. (3) Dari ketiga guru di atas semuanya sudah meningkatkan prestasi belajar siswanya sehingga bagi siswa yang memiliki prestasi menurun bisa ada peningkatan. (4) Dari ketiga guru yaitu guru Bahasa Indonesia, Matematika dan IPA semuanya dalam menyampaikan pembelajaran dimengerti oleh siswa(i)nya. Hanya saja perlu ditingkatkan lagi terutama bagi guru Matematika dalam menyampaikan pembelajaran ketika siswanya tidak mengerti perlu ada pengulangan penjelasan sehingga siswa yang mendengarkan penjelasan bisa mengerti dengan baik. (5) Dari ketiga guru tersebut harus selalu tepat waktu dalam mengajar sehingga jam pelajaran tidak berkurang dan siswa(i) tidak ribut dan tidak keluar masuk dalam kelas. (6) Siswa perlu mengetahui bahwa prestasi merupakan hasil yang telah dicapai dari setiap pembelajaran bukan hanya tiga pelajaran yang telah penulis teliti di atas tetapi semua pelajaran yang telah diajarkan oleh setiap guru di bidang mata pelajaran. Oleh karena itu siswa yang memiliki prestasi baik adalah siswa yang mau belajar sama seperti yang telah dijelaskan dalam bab II.
\end{abstract}

Kata Kunci: Peran, Strategi Mengajar Guru, Prestasi Belajar, Siswa.

\section{Pendahuluan}

\section{Latar Belakang Masalah}

Dengan adanya beragam teknologi maka kemauan siswa dalam belajar akan semakin berkurang dikarenakan siswa lebih memanfaatkan media elektronik mereka dibanding fokus dengan belajar yang disampaikan oleh guru di dalam kelas. Kebanyakan siswa tidak lepas dari games dan internet yang ada di Handphone mereka sehingga menyita banyak waktu seperti malas mengerjakan tugas-tugas dan susah memahami pelajaran yang diberikan oleh guru di sekolah. Bahkan kebanyakan orang tua sekarang memberikan Handphone yang canggih kepada anak-anak mereka untuk memudahkan mereka berkomunikasi. Namun hal ini belum seharusnya bagi mereka yang masih di bawah umur. 
John Santrock mengungkapkan, dunia pendidikan yang semakin maju ini tentunya menuntut prestasi seseorang anak. Orang tua mendidik anaknya dengan penuh tanggung jawab untuk mengupayakan peningkatan prestasi belajar anaknya. Bukan hanya guru yang berperan dalam prestasi anak tetapi orang tua yang harus berperan penting dalam membimbing maupun mendidik anaknya untuk lebih baik ke depannya. ${ }^{1}$ Terkadang orang tua memberikan tugas ini kepada guru, mereka menganggap bahwa gurulah yang mendidik anaknya bukan orang tua, tugas orang tua hanya menyekolahkan anaknya. Namun pendapat ini salah karena anak mulai belajar dari rumah sendiri mengenali keluarga dan lingkungan di mana mereka berada, itu adalah tahap belajar anak.

Belajar merupakan proses pendidikan yang terjadi di sekolah, di rumah bahkan di lingkungan sekitar kita. ${ }^{2}$ Soemanto mengatakan, belajar adalah suatu proses bukan suatu hasil. Belajar secara aktif dan interaktif dengan menggunakan berbagai bentuk perbuatan untuk mencapai suatu tujuan yang baik. Individu dikatakan belajar atau tidak sangat tergantung kepada kebutuhan dan motivasinya. Kebutuhan dan motivasi seseorang menjadi tujuan dalam belajar. Sedangkan motivasi akan timbul jika seseorang memiliki minat yang besar. $^{3}$

Ngainun Naim mengatakan, guru adalah sosok yang rela mencurahkan sebagian besar waktunya untuk mengajar dan mendidik siswa, sementara penghargaan dari sisi material, misalnya sangat jauh dari harapan. Gaji seorang guru rasanya terlalu jauh untuk mencapai kesejahteraan hidup layak sebagaimana profesi lainnya. Hal itulah tampaknya yang menjadi salah satu alasan mengapa guru disebut sebagai pahlawan tanpa tanda jasa. ${ }^{4}$ Setiap guru mengajar menginginkan supaya semua siswa yang diajar bisa lulus dengan berkelakuan baik dan nilai yang memuaskan dalam setiap mata pelajaran. Guru bukan hanya ingin mendapatkan pangkat yang tinggi tetapi bagaimana guru tersebut bisa mengubah kelakuan buruk siswa menjadi berkelakuan baik.

Kelulusan siswa merupakan impian bagi setiap guru, orang tua dan siswa untuk mendapat ijazah dengan prestasi yang baik. Lulus tidaknya seseorang tergantung pada minat belajar. Siswa yang kurang memiliki minat dalam belajar akan mendapat nilai tidak sesuai dengan yang diharapkan. Dalam perkembangan saat ini pendidikan bukan hanya tamatan TK, SD, SMP, SMA, dan SMK tetapi mampu bersaingan dalam menghadapi era globalisasi seperti sekarang ini. Oleh karena itu, guru dituntut untuk menamatkan siswa-siswi yang mampu bersaing secara sehat dengan orang lain untuk mendapatkan prestasi yang baik.

Pada umumnya istilah strategi digunakan dalam dunia militer yang diartikan sebagai cara menggunakan seluruh kekuatan militer untuk menang dalam dunia perang. Seorang yang berperan dalam mengatur strategi, untuk memenangkan peperangan sebelum melakukan suatu tindakan, ia akan menimbang bagaimana kekuatan pasukan yang dimilikinya baik dilihat dari kuantitas maupun kualitas; misalnya kemampuan setiap

\footnotetext{
${ }^{1}$ John W. Santrock, Psikologi Pendidikan (Jakarta: Prada Media Grup, 2008), 95.

${ }^{2}$ Roida Eva Flora Siagian, "Pengaruh Minat dan Kebiasaan Belajar Siswa Terhadap Prestasi Belajar Matematika," Jurnal Formatif 2, No. 2 (Desember 2012):123, diakses 21 Februari 2018, http://www.academia.edu/7189642/Jurnal_Formatif_2_2_122-131_-122_ _Pengaruh_Minat_Dan_Kebiasaan_Belajar_Siswa_Terhadap_Prestasi_Belajar_Matematika.

${ }^{3}$ Keke T. Aritonang, "Minat dan Motivasi dalam Meningkatkan Hasil Belajar Siswa," Jurnal Pendidikan Penabur 7, No. 10 (Juni 2008):13, diakses 22 Februari 2018, http://www.academia.edu/9717290/Minat_dan_Motivasi_dalam_Meningkatkan_Hasil_Belajar_Siswa.

${ }^{4}$ Ngainun Naim, Menjadi Guru Inspiratif (Yogyakarta: Pustaka Pelajar, 2009), 1.
} 
personal, jumlah dan kekuatan persenjataan, motivasi pasukannya, dan sebagainya. ${ }^{5}$ Oleh karena itu, strategi dalam dunia militer adalah suatu ancangan untuk mencapai sasaran dalam berperang, menyusun anggota-anggota dalam menempatkan mereka di suatu tempat dalam berperang melawan musuh.

J.R. David mengatakan, dalam dunia pendidikan strategi diartikan sebagai rencana untuk mencapai tujuan pembelajaran. Strategi pembelajaran merupakan perencanaan yang sudah dibuat sesuai dengan target yang ingin dicapai dalam suatu pendidikan tertentu. Strategi pembelajaran ada dua yaitu Pertama, menyusun rencana pembelajaran yang ingin dilakukan seperti pembuatan RPP, Silabus dan lain sebagainya. Kedua, strategi yang telah disusun dapat dipakai dalam proses belajar mengajar. ${ }^{6}$

Menurut Kamus Besar Bahasa Indonesia, strategi adalah "rencana yang cermat mengenai kegiatan untuk mencapai sasaran khusus."7 Trianto mengatakan, secara umum strategi mempunyai pengertian suatu garis-garis besar haluan untuk bertindak dalam mencapai sasaran yang telah ditentukan. Dihubungkan dengan belajar mengajar, strategi bisa diartikan sebagai pola-pola umum kegiatan guru dan anak didik dalam mewujudkan kegiatan belajar mengajar untuk mencapai tujuan yang telah digariskan. ${ }^{8}$ Sedangkan menurut Sidjabat mengatakan, strategi dalam pembelajaran mengandung arti yaitu bagaimana guru merencanakan kegiatan mengajar sebelum melaksanakan pembelajarannya kepada peserta didiknya. Ketika merencanakan strategi pembelajaran, guru pun harus mempertimbangkan tujuan, sifat dari bahan pengajaran, peserta didik yang belajar, serta fasilitas, ruang, dan waktu belajar. ${ }^{9}$ Oleh karena itu, strategi dalam dunia pendidikan adalah menyiapkan bahanbahan dalam mengajar. Dengan adanya bahan-bahan dalam mengajar siswa akan lebih muda dalam memahami materi yang dipelajari, guru pun tidak kesulitan dalam mengajar oleh karena banyaknya bahan yang disiapkan. Strategi adalah rencana kegiatan belajar mengajar yang disusun untuk mencapai tujuan tertentu. Sebelum melakukan strategi perlu ada perumusan yang jelas untuk dapat diukur keberhasilannya dalam mencapai strategi tersebut.

Mengajar merupakan bagian dari perilaku profesional guru yang menjadi ikon atau penampang dari keseluruhan penampilannya sebagai unsur pendidikan. ${ }^{10}$ Kegiatan belajar mengajar di kelas dilakukan oleh seorang guru sesuai dengan gaya mengajarnya, sebagian guru membuka buku pelajaran dan menjelaskan materi yang terdapat di dalam buku tersebut, sebagian guru yang lain menanyakan kepada siswa atau peserta didik tentang penguasaan materi yang akan dipelajari, kemudian dilanjutkan dengan tanya jawab, diskusi, tugas, dan lain-lain. ${ }^{11}$ Tujuan dari strategi mengajar guru adalah agar siswa dapat menerima semua pembelajaran dengan baik dan memperoleh prestasi yang baik pula.

\footnotetext{
${ }^{5}$ Wina Sanjaya, Strategi Pembelajaran Berorientasi Standar Proses Pendidikan (Jakarta: Kencana, 2006), 6 .

${ }^{6}$ Mohamad Syaif Sumantri, Strategi Pembelajaran Teori dan Praktik di Tingkat Pendidikan Dasar (Jakarta: RajaGrafindo Persada, 2015), 279.

${ }^{7}$ Tim Penyusun Kamus Pusat Bahasa, Kamus Besar Bahasa Indonesia (Jakarta: Balai Pustaka, 2001), 1092, s.v. "Strategi".

${ }^{8}$ Trianto, Mendesain Model Pembelajaran Inovatif Progresif (Jakarta: Kencana Prenada Media Grup, 2009), 139.

${ }^{9}$ Sidjabat, Mengajar Secara Profesional (Bandung: Yayasan Kalam Hidup, 2009), 265.

${ }^{10}$ Mohamad Surya, Psikologi Guru Konsep dan Aplikasi dari Guru untuk Guru (Bandung: Penerbit Alfabeta, 2013), 201.

${ }^{11}$ Martinis Yamin, Desain Pembelajaran Berbasis Tingkat Satuan Pendidikan (Jakarta: Referensi, 2012), 58.
} 
Sesuai dengan pembahasan di atas bahwa tujuan dari strategi mengajar guru agar siswa memperoleh prestasi yang baik. Penulis ingin meneliti bagaimana peran strategi mengajar guru terhadap prestasi siswa di Sekolah Dasar Kristen Kalam Kudus. Penulis tertarik ingin meneliti sekolah tersebut karena sekolah tersebut memiliki jumlah siswa yang cukup untuk diteliti.

\section{Pokok Masalah}

Dengan melihat penjelasan latar belakang di atas maka yang menjadi pokok masalah dalam penulisan skripsi ini adalah: Bagaimana peran strategi mengajar guru terhadap prestasi belajar siswa kelas V di SD Kalam Kudus Makassar?

\section{Tujuan Penelitian}

Adapun tujuan penulisan yang ingin dicapai dalam penulisan skripsi ini adalah mengetahui peran strategi mengajar guru terhadap prestasi belajar siswa kelas V di SD Kristen Kalam Kudus Makassar.

\section{Manfaat Penelitian}

Adapun manfaat yang diperoleh dari penulisan skripsi ini adalah:

Pertama, agar dapat dijadikan sebagai pedoman guru dalam strategi mengajar.

Kedua, sebagai bahan evaluasi bagi SD Kristen Kalam Kudus Makassar.

Ketiga, sebagai salah satu persyaratan dalam menyelesaikan pendidikan strata satu di Sekolah Tinggi Theologia Jaffray Makassar.

\section{Metode Penelitian}

Metode penelitian yang digunakan dalam penulisan skripsi ini dengan menempuh beberapa cara antara lain:

Pertama, menggunakan buku-buku, jurnal dan internet sebagai bahan atau referensi yang berkaitan dengan judul yang dibahas oleh penulis.

Kedua, wawancara kepada guru dan membagikan angket kepada siswa di SD Kristen Kalam Kudus tentang kendala-kendala yang ada dalam proses pembelajaran untuk mendapat data yang lengkap.

\section{Batasan Penelitian}

Berdasarkan judul "Peran Strategi Mengajar Guru Terhadap Prestasi Belajar Siswa Kelas V Di SD Kristen Kalam Kudus Makassar," maka pembahasan penulisan ini terbatas pada sampel SD Kristen Kalam Kudus, Makassar dan populasi guru mata pelajaran Bahasa Indonesia, Matematika, IPA, serta siswa kelas V SD Kristen Kalam Kudus.

\section{Kesimpulan}

Sesuai dengan judul yang dibahas dalam penulisan skripsi ini, yaitu "Peran Strategi Mengajar Guru Terhadap Prestasi Belajar Siswa Kelas V di SD Kristen Kalam Kudus Makassar," maka penulis menyimpulkan beberapa hal sebagai berikut:

Pertama, strategi pembelajaran adalah kegiatan guru dalam proses pembelajaran yang dapat memberikan kemudahan kepada siswa agar dapat mencapai tujuan pengajaran yang telah ditetapkan. Strategi belajar mengajar merupakan proses belajar mengajar agar tercapai tujuan pengajaran yang efektif dan efisien. Strategi pembelajaran merupakan 
perpaduan dari urutan kegiatan, cara pengorganisasian materi pelajaran dan siswa, peralatan dan bahan, serta waktu yang digunakan dalam proses pembelajaran.

Kedua, dalam proses belajar mengajar guru harus banyak memiliki strategi dan pembaharuan-pembaharuan dalam proses belajar mengajar sehingga membuat suasana kelas menjadi internatif dan strategi pembelajaran juga menyangkut materi-materi yang ada dalam pengajaran sehingga tujuan dari pembelajaran tersebut dalam tercapai.

Ketiga, penerapan strategi pembelajaran harus disesuaikan dengan kondisi baik internal (dari dalam diri siswa) maupun eksternal (dari luar siswa) sehingga tujuan pembelajaran dapat tercapai dengan baik sesuai yang diinginkan sebelumnya.

Keempat, dalam belajar sangat dibutuhkan motivasi dari kedua orang tua siswa dan juga guru sehingga siswa dapat belajar dengan baik dan mampu mengaplikasikan setiap pelajaran yang didapatkan di sekolah untuk dapat dikembangkan. Nilai prestasi siswa yang menurun bisa menjadi meningkat sesuai yang diharapkan. Sebagai orang tua harus memperhatikan anak-anak mereka dalam belajar seperti menyuruh belajar dan jika ada tugas yang diberikan oleh gurunya di sekolah bisa dikerjakan di rumah dengan bimbingan orang tua.

Kelima, sebagai siswa tugasnya adalah belajar. Siswa yang nilai prestasinya menurun harus lebih ditingkatkan lagi dalam belajar, sehingga nilai prestasi bisa meningkat. Sedangkan siswa yang prestasinya tinggi juga tugasnya adalah belajar. Nilai yang baik atau tinggi bisa saja menurun jika tidak belajar. Oleh karena itu semua siswa tugas utamanya adalah belajar. Semua siswa dalam belajar perlu bimbingan dari guru dan juga orang tua.

\section{Kepustakaan}

Ali, Mohamad. Penelitian Kependidikan Prosedur dan Strategi. Bandung: Angkasa, 1985.

Aritonang, Keke T. "Minat dan Motivasi dalam Meningkatkan Hasil Belajar Siswa." Jurnal Pendidikan Penabur 7, No. 10 (Juni 2008):11-21. Diakses 22 Februari 2018. http://www.academia.edu/9717290/Minat_dan_Motivasi_dalam_Meningkatkan_Hasi 1_Belajar_Siswa.

Astika, Made, DAN Bunga, Selvianty. "Hubungan Kompetensi Sosial Guru Kristen

Terhadap Perkembangan Karakter Siswa: Tantangan Pendidikan Kristen Dalam

Mencerdaskan Youth Generation" Jurnal Jaffray [Online], Volume 14 Nomor 1 (10 Maret 2016).

Basri, Hasan. Paradigma Baru Sistem Pembelajaran. Bandung: Pustaka Setia, 2015.

Barnadib, Sutari Imam. Pengantar Ilmu Pendidikan Sistematis. Yogyakarta: ANDI Offset, 1989.

Busthan, Paskalinus C. Catatan Kuliah Seminar Pendidikan Agama Kristen. Makassar: Sekolah Tinggi Theologia Jaffray, 2018. Belum dipublikasikan.

Drost, Josephus Ignatius Gerardus Maria. Sekolah: Mengajar atau Mendidik? Yogyakarta: Kanisius, 1998. 
Gunarsa, Singgih D., dan Y. Singgih D. Gunarsa. Psikologi Perkembangan Anak dan Remaja. Jakarta: BPK Gunung Mulia, 1991.

Mulia, 2011. . Psikologi Perkembangan Anak dan Remaja. Jakarta: BPK Gunung Mulia, 2010. . Psikologi Praktis Anak, Remaja, dan Keluarga. Jakarta: BPK Gunung

Hulu, Yuprieli, dkk. Bertumbuh Dalam Kristus. Jakarta: BPK Gunung Mulia, 2012.

I. L. Pasaribu dan B. Simandjuntak. Proses Belajar Mengajar. Bandung: Tarsito, 1983

Karwono dan Heni Mularsih. Belajar dan Pembelajaran. Depok: Rajawali Pers, 2017. Belajar Dan Pembelajaran Serta Pemanfaatan Sumber Belajar. Depok: RajaGrafindo Persada, 2017.

Khan, Shafiqui Ali. Filsafat Pendidikan Al-Ghazali. Bandung: Pustaka Setia, 2005.

Kuhns, Janet. "Mengajar Secara Kreatif" Jurnal Jaffray [Online], Volume 1 Nomor 1 (5 Januari 2005)

Kunarsih, Imas and Berlin Sani. Lebih Memahami Konsep dan Proses Pembelajaran. Jakarta: Bumi Aksara, 2017.

Langgulung, Hasan. Pendidikan dan Peradaban Islam. Jakarta: Pustaka Al-Husna, 1985.

Naim, Ngainun. Menjadi Guru Inspiratif. Yogyakarta: Pustaka Pelajar, 2009.

Nainggolan, John M. Guru Agama Kristen Sebagai Panggilan dan Profesi. Bandung: Bina Media Informasi, 2010.

Nidawati. "Belajar Dalam Perspektif Psikologi dan Agama." Jurnal Pionir 1, No. 1 (JuliDesember 2013):13-28. Diakses 20 Agustus 2018. https://jurnal.arraniry.ac.id/index.php/Pionir/article/download/153/134.

Nurdin, Syaifudin, dan Basyiruddin Usman. Guru Professional dan Implementasi Kurikulum. Jakarta: Ciputat Pers, 2002.

Popham, W. James dan Eva L. Baker. Bagaimana Mengajar Secara Sistematis. Yogyakarta: Kanisius, 1981.

Rivai, Viithzal, dan Sylviana Murni. Education Manajement: Analisis Teori dan Praktik. Jakarta: Rajawali Pers, 2012.

Santrock, John W. Psikologi Pendidikan. Jakarta: Prada Media Grup, 2008.

Siagian, Roida Eva Flora. "Pengaruh Minat Dan Kebiasaan Belajar Siswa Terhadap Prestasi Belajar Matematika." Jurnal Formatif 2, No. 2 (Desember 2008):122-123. Diakses 21 Februari 2018. http://www.academia.edu/7189642/Jurnal_Formatif_2_2_122-131_122_Pengaruh_Minat_Dan_Kebiasaan_Belajar_Siswa_Terrhadap_Prestasi_Belajar_ Matematika. 
Sumantri, Mohamad Syair. Strategi Pembelajaran: Teori dan Parktik di Tingkat Pendidikan Dasar. Jakarta: PT RajaGrafindo Persada, 2015.

Surya, Mohamad. Psikologi Guru Konsep dan Aplikasi dari Guru untuk Guru. Bandung: Penerbit Alfabeta, 2013.

Sidjabat, B. S. Mengajar Secara Profesional. Bandung: Yayasan Kalam Hidup, 2009.

Syah, Muhibbin. Psikologi Pendidikan dan Pendekatan Baru. Bandung: Remaja Rosdakarya, 2010.

Sardiman. Interaksi dan Motivasi Belajar Mengajar. Jakarta, RajaGrafindo Persada Offset, 2000.

Sanjaya, Wina. Strategi Pembelajaran Berorientasi Standar Proses Pendidikan. Jakarta: Kencana, 2006. . Kurikulum \& Pembelajaran. Jakarta: Rajawali Pers, 2011. . Kurikulum dan Pembelajaran. Jakarta: RajaGrafindo, 2011. . Penelitian Pendidikan. Jakarta: Kencana Prenada Media Group, 2013. . Kurikulum dan Pembelajaran Teori dan Praktek Pengembangan Kurikulum Tingkat Satuan Pendidikan (KTSP). Jakarta: Kencana Prenada Media Group, 2008.

Sudjana, Nana. Penilaian Hasil Proses Belajar Mengajar. Bandung: Remaja Rosdakarya, 1989.

Setiawan, Mary Go. Merobos Dunia Anak. Bandung: Yayasan Kalam Hidup, 2004.

Silver, Harvey F., Richard W. Strong, dan Matthew J. Perini. Strategi-strategi Pengajaran. Jakarta: Rineka Cipta, 2012.

Trianto. Mendesain Model Pembelajaran Inovatif Progresif. Jakarta: Kencana Prenada Media Grup, 2009.

Tim Didaktik Metodik Kurikulum IKIP Surabaya. Pengantar Didaktik Metodik Kurikulum PBM. Jakarta: CV Rajawali, 1984.

Tim Pengembangan Ilmu Pendidikan. Ilmu \& Aplikasi Pendidikan. Jakarta: Imperial Bhakti Utama, 2007.

Uno, Hamzah B. Nina Lamatenggo. Tugas Guru Dalam Pembelajaran. Jakarta: Bumi Aksara, 2016.

Winkey, W. S. Psikologi Pembelajaran. Jakarta: Gramedia, 1989.

Wilgito, Bimo. Bimbingan Dan Penyuluhan Disekolah. Yogyakarta: Yayasan Penerbit Fakultas Psikologi, 1982.

Wahidmurni, Alfin Mustikawan dan Ali Ridho. Evaluasi Pembelajaran / Kompetensi dan Praktik. Yogyakarta: Nuha Litera, 2010. 
Wijaya, Hengki (ed.). Metodologi Penelitian Pendidikan Teologi. Makassar: Sekolah Tinggi Theologia Jaffray, 2016.

Yamin, Martinis. Desain Pembelajaran Berbasis Tingkat Satuan Pendidikan. Jakarta: Referensi, 2012.

Yaumi, Muhammad. Pendidikan Karakter Landasan, Pilar \& Implementasi. Jakarta: Prenadamedia Gruop, 2014. 